\title{
FLORISTIC REPORT ON THE MARINE BENTHIC ALGAE OF SELECTED ISLANDS IN THE GILBERT GROUP
}

\author{
By ROY T. TSUDA \\ BOTANY DEPARTMENT, UNIVERSITY OF HAWAII
}

Reprinted from

ATOLL RESEARCH BULLETIN NO. 105

THE PACIFIC SCIENCE BOARD

NATIONAL ACADEMY OF SCIENCES - NATIONAL RESEARCH COUNCIL

\section{UNIVERSITY OF HAWAII \\ HAWAII MARINE LABORATORY}


ATOLI RESEARCH BUIJEIIN

No. 105

Floristic report on the marine benthic algae of selected islands in the Gilbert Group

by

Roy T. Tsuda

Issued by

THE PACIFIC SCIENCE BOARD

National Academy of Sciences--National Research Council

Washington, D. C.

September 30,1964 
Floristic report on the marine benthic algae

of selected islands in the Gilbert Group $1 /$

by

Roy T. Tsuda $2 /$

The Gilbert Islands are a part of the Gilbert and Ellice Islands Crown Colony of Great Britain. They lie in the Pacific Ccean directly southeast of the Marshall Islands and are located between the parallels of $2^{\circ} 4^{\prime} \mathrm{S}$. and $3^{\circ} 30^{\prime} \mathrm{N}$. latitude, and the meridians of $172^{\circ} 30^{\prime} \mathrm{E}$. and $177^{\circ} 15^{\prime}$ E. longitude. All of the islands in this group are low islands related to atolls. They are inhabited by Micronesian and Melanesian people who are creatly dependent on materials from the sea for food.

Past experiences by the natives have been (Cooper, 1964) that certain species of reef fishes when eaten are extremely toxic in one area and nontoxic in another area. Because fish is one of the primary diet items of the natives, various investigations have been undertaken to find the causes of this toxicity which applies specifically to fishes inhabiting reefs. Only reef fishes from certain areas are affected, therefore it seems (Randall, 1958) that a likely cause of this toxin lies in their food or habits. Since Helfrich \& Banner (1963) have shown that the toxin can be transmitted through the food chain, and is likely (Helfrich, et al., ms.) to be transmitted to the large carnivores by bottom feeding herbivores, the marine algae, especially the small filamentous species, head the list as the most likely sources of the toxin.

At present, a study is underway at the Hawaii Marine Laboratory, under the direction of Drs. Albert H. Banner and Philip Helfrich3/, to further investigate the "toxic reef fishes" in the Pacific area. One of the principal steps associated with this project is to identify the marine algae associated with various "toxic" situations.

Of the sixteen islands in the Gilbert Group, only for Onotoa Atoll has anything extensive been published on the algae. This is the 1957 "Prelininary Report on the Flora of Onotoa Atoll," wherein Noul gives a list of the algae he collected from this atoll, the identification to species having been done by Moul, except for the Myxophyta which were identified by $\mathrm{Dr}$. Francis Drouet4/. In Appendix I of his

I/ Report no. 2, Hawaii Viarine Laboratory, University of Hawaii, Honolulu, Hawaii 96822.

2/ Botany Department, University of Hawaii, Honolulu, Hawaii; work done and supported in art by funds provided by contract (GB404), between the University of Hawaii and the National Science Foundation.

3/ University of Hawaii, Honolulu, Hawaii.

4/ Academy of Natural Sciences, Philadelphia, Fennsylvania. 
"Relort on the Gilbert Islands: Some Aspects of Human Ecology," Catala gives (1957) a list of algae (all lyxophyta) collected by his wife in July 1951. These were also identified by Dr. Drouet. Catala's algae were collected in fish ponds from only two islands, from the northern and southern fish ponds on Ilukunau and from a fish pond on Beru. ithere has been no extensive collection of algae from the other islands of the Gilbert Group. Dr. V. J. Chapman (1955) has published a list of the algae collected from Funafuti Atoll, in the illice Group which is south of the Gilbert Group.

Mrs. Jane Cooper $5 /$ sent some bottles of preserved alfae collected from six of the islands of the Gilbert Group in areas where the fish were toxic or nontoxic. These wore sent to the University of lawaii at the request of Drs. Banner and Helfrich and thus provided an opportunity for the author to extend our knowledge of algal floristics in the Central Pacific and at the same time contribute some phycological information specifically useful to the poison fish studies. The first step undertaken was to sort the algae in each collection into their respective genera and give each entity from each collection a number. The numbers run from 18771 to 18952 and are permanently recorded in Dr. ilaxwell S. Doty's6/ notebook number 73. The specimens themselves are being deposited in Dr. Doty's herbarium.

In identifyin the algae, particul rly those species within the Rhodophyta, and in citing bibliographies of original publications, Dawson's (1954, 1956) papers have been the most useful. Other references which proved of imense value while working with the present Chlorophyta are Igerod's (1952) paper on the siphonaceous algae, Bubank's (1946) paper on Caulerpa, Dr. Williail J. Gilbert's?/ (unpub.) field manual of Hawaiian Chlorophyta, and Hillis' (1959) paper on Halimeda. The manuscript manual on Hawaiian thaeophyta by Dr. Doty and Nir. Jan Newhouses/ has been primarily used in identifying the species of Phaeophyta.

The followin; is a list of the atolls and the algal habitats of each of the Cooper collections from the Gilbert Group. Reefs inlabited by "toxic fishes" are designated for convenient reference here as "toxic reef flats," or "toxic areas." Cooper (1964) provides a more complete discussion of these areas.

ABEMAIA ATOLL, Abemama Island $\left(0^{\circ} 21\right.$, N. lat., 173 51 ' i. long•): passage between ocean and lagoon at low tide in about three feet of water along the eastern side of the island at the Government Village, July 1962 $(18895-18898,18900,18902,18903)$.

5/ Department of Co-operative Societies, Suva, Tiji.

6/ University of Hawaii, Honolulu, Hawaii.

I) Albion College, Albion, Michigan.

8/ Dole Corporation, Honolulu, Hawaii. 
MARAKII ATOLI, Marakei Island ( $2^{\circ} 03^{\prime} \mathrm{N}$. lat., $173^{\circ} 25^{\prime}$ E. Iong.): "toxic reef" south of Rawanawi Village, below low water mark, July 1962 (18771-18786); "toxic reef", taken from the top of rocks below low water mark which do not quite dry out but have a few inches of water on them at low tide, July 1962 (13787-18793); "toxic reef flat" south of Rawanawi Village, July 1962 (18794-18800, 18940-18943, 18946); "toxic area" south of Rawanawi Village, stones from bottom of surge channels which are twenty to thirty feet deep, July 1962 (18905-18909, 18911, 18912, 18919, 18921, 13922, 18926, 18927, 18930); "toxic reef" near the Village of Rawanawi, July 1962 ( $18936-18938)$.

NONOUTI ATOLL, Nonouti. Island ( $0^{\circ} 49^{\prime}$ S. Iat., $174^{\circ} 29^{\prime}$ E. Iong.): ocean reef flat subject to continual heavy surf, July 1962 (18888-18890).

NUKUNAU ATOLL, Nukunau Island ( $1^{\circ} 19^{\prime}$ S. lat., $176^{\circ} 23^{\prime}$ E. Iong.): "toxic reef" near the Village of Rungata, July 1962 (18892-18894).

TAMANA ATOLI, Tamana Island $\left(2^{\circ} 39^{\prime} \mathrm{S}\right.$. lat., $175^{\circ} 58^{\prime}$ E. Iong.): bottom and side of newly blasted channel in the reef, July 1962 (18948, 18952).

TARANA ATOLL, Betio Island $\left(1^{\circ} 30^{\prime}\right.$ N. lat., $173^{\circ} 00^{\prime}$ E. Iong.): western reef with an area of mostly sand, July 1962 (18801-18804, 1881718825); southern reef near shoreline with a large sandy pool with few algae present, July 1962 (18805-18810, 18826-18833, 18884-18886); southern reef at western end which borders the ocean and dries out at low tide, July 1962 (18835-18845); southern reef below low water mark exposed to heavy surf, July 1962 (18857-18859); southern reef in a small tide pool on the ocean edge which does not dry out, July 1962 (1885018856); northwest reef which is a "toxic area" of coarse sand and stones with a strong current, July 1962 (18811-18816); western reef with dazzling white sand and a few large stones covered with algae, July 1962 (1836018862, 18864-18866); lagoon beach which is sandy with small stones and large sting ray holes, June 1962 (18867-18874); beach reef in lagoon about three feet below low water mark, June 1962 (18875-18883).

The following is an annotated list of the blue-green, green, brown, and red algae found in the collections from the islands in the Gilbert group listed in the above paragrajhs. The collection numbers for the specimens are listed with the species. Annotations have been restricted merely to pertinent taxonomic and ecological information which the author thought of particular value.

\section{MYXOPHYTA}

Calothrix crustacea Thur.

Tarawa: 18807A (epiphytic on Padina).

Entophysalis deusta (Mienegh.) Drouet \& Daily

Tarawa: 18816. 


$$
-4-
$$

Hormothamnion enteromorphoides Grun.

Marakei: $18796,18797$.

Fydrocoleum cantharidosmum (Mont.) Gom.

Marakei: 18797; Tarawa: 18872.

Hyarocoleum Iyngbyaceuin Kütz.

Marakei: 18796.

Lyngbya aestuarii (Niert.) Lyngb.

Marakei: 18795, 18796, 18807A (epiphytic on Padina).

Lyngbya Iutea (ig.) Gom.

Marakei: 18781 ; Tarawa: 18883.

Lyngbya semiplena $(A g.) \mathrm{J} \cdot \mathrm{Ag} \cdot$

Marakei: 18781.

Mastigocoleus testarum (Lagerh.) Born. \& Flah.

Tarawa: 18816 .

Microcoleus chthonoplastes (Mert.) Zanard.

Marakei: 18795, 18797; Tarawa: 18883.

Schizothrix calcicola (Ag.) Gom.

Nonouti: 18888 (epiphytic on green algae); Marakei: 18795, 18797,

18807A (epiphytic on Enteromorpha); Tarawa: 18816, 16.872, 10883, 18384.

This species was present in most of the collections sent to Dr. Drouet. Drouet says that the morine ecophenes (ecolosical jrowthforms) of Jchizothrix calcicola (Ag.) Gom. are such familiar "species" as Plectonema terebrans, Phormidium crosbyanum, and Iyngbya rivulariarum. Dr. C. M. Palmer has found a virus which attacks all ecophenes which Drouet has indicated as $\underline{S}$. calcicola in various culture collections.

Symploca hydnoides Irhtz.

Marakei: $18793,18797$.

\section{CHLOROPHYTA}

Acetabularia mobii solms-Laubach, 1895: 30, pl. 4 (fig. 1); Egerod, 1952: 411, fig. $23 i$.

Marakei: 18909 (fertile).

Thalli about $5 \mathrm{~mm}$ high, having $15-17$ rays adhering to each other, with approximately 25-35 spherical cysts in each ray. 
Boodlea composita (ilarvey) Brand, 1904: 187; Egerod, 1952: 362, fig. 6a and $\mathrm{pl} \cdot 32 \mathrm{a}$.

Maraliei: 18773; Tarawa: 18862.

Both collections forming dense spongy mats intermixed with Hypnea.

Caulerpa racenosa var. macrophysa (Kutz.) Taylor, 1928: 101, pl. 12

(fig. 3), pl. 13 (fig. 9); Bubank, 1946: 420, fig. 2n.

Tarawa: 18304, 18811, 18823, 18826, 18337, 18859, 18860, 18879.

Caulerpa racemosa var. peltata (Iamx.) Eubank, 1946: 421, figs. 2r-s.

Tarawa: 18839.

Caulerpa racemosa var. turbinata (J. Ag.) iubank, 1946: 420, figs. 20p-q. Tarawa: 18822, 18838, 18864.

Caulerpa serrulata var. typica f. Iata (Weber-van Boose) Tseng, 1936:

178, pl. 1; Eubank, 1946: 418, fig. 2h.

Marakei: 18783; Tarawa: 10810.

Caulerpa serrulata var. typica f. angusta (Weber-van Boose) Eubank, 1946: 418 , fig. $2 j$.

Tarawa: 18803, 18809 , 18835, 18850.

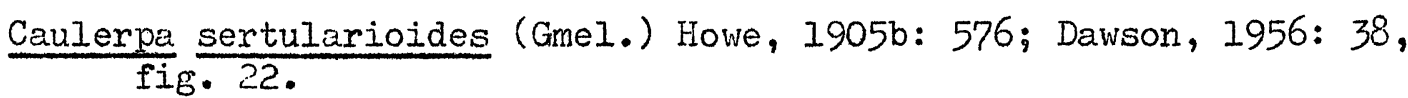

Tarawa: 18802, 18806, 18820, 18827, 18853.

Caulerpa urvilliana Montagne, 1845: 21; Dawson, 1956: 37, fig. 21.

Marakei: 18788, 18799.

Both collections consisting of small thalli which were identified by Dr. William J. Gilbert.

Chlorodesmis hildebrandtii A. \& . S. S. Gepp, 1911: 16, 137, figs. 74, 75; Egerod, 1952: 377, fig. 9b and pl. 34a; Dawson, 1954: 394, fig. Ilf.

Tarawa: 18821.

Filaments about $20 \mathrm{~mm}$ in length and $80 \mu$ in width having a distinct bead-like swelling above each constriction. This collection resembles Egerod's illustration cited above which shows filaments constricted at frequent intervals, as opposed to Dawson's illustration which has fewer constrictions.

Cladophora repens (J. Ag.) Harvey, 1958: 236; Taylor, 1960: 82.

Marakei: 18942.

Small dichotomously branched filaments about $1 \mathrm{~cm}$ tall which seem to fit Taylor's description. 
Cladophora sp.

Nonouti: 18390.

Filaments natted forming a small brown clump about $1 \mathrm{~cm}$ high. Codium edule Silva in Bgerod, 1952: 392, fig. 18a-c and pl. 35.

Tarawa: 18857.

Thalli repent with the branches adhering to each other and with numerous hairs projecting from the utricles.

Codium reediae Silva in Igerod, 1952: 3.99, fig. 17 and pl. 36.

Tarawa: 18840.

Thallus $9 \mathrm{~cm}$ tall with dichotomous and irregular branches not adhering to each other. The upper portion of the thallus is slightly compressed and numerous hairs can be seen upon macroscopic examination. The utricles are pyriform to truncate in shape, often $532 \mu$ in length and $226 \mu$ in width.

Dictyosphaeria cavernosa (Forsk.) Boergesen, 1932: 2, pl. I (fig. 1); Egerod, 1952: 350, fig. le-g.

Nonouti: 13889.

Clump approximately $2.5 \mathrm{~cm}$ broad comprised of one layer of cells, which lack spine-like processes on the interior surfaces of their walls. Segments polygonal, $700 \mathrm{H}$ in diameter with hapteroid cells present as in fig. If-g, of Egerod's paper.

It is surprising that Dictyosphaeria versluysii Weber-van Bosse was not found among these collections.

Enteromorpha intestinalis (I.) Link, 1820: 5; Dawson, 1954: 383, fig. 6c.

Tarawa: 18828, 18871.

Filaments about $3 \mathrm{~cm}$ tall covering a small piece of coral.

Enteromorpha sp.

Tamana: 18948 ,

This collection consists of small immature filaments covering a piece of coral.

Halimeda gracilis Harvey, ex J. Ag., 1887: 82; Hillis, 1959: 356 , pl. 2(fig. 4), pl. 5 (fig. 7), pl. 6 (fig. 9), pl. 7 (fig. 2), pl. 10 .

Nukunau: 18892.

No distinct holdfast visible. Serments cylincirical in shape toward the base, with tear-shaped seginents in the apical portions of the thalli. 
Halimeda incrassata (ElIis) Lamouroux, 1812: 186; Hillis, 1959:

365, pl. 4 (figs. 1-2), p1. 5 (fig. 21), pl.6 (figs. 2l-24), pl. 12.

Abemama: 18898; Tarawa: 13801, 18817.

Halimeda opuntia (L.) Lamx., 1812: 136; Hillis, 1959: 359, pl. 2 (figs. 7-8), pl. 5 (figs. 3-4), pl. 6 (fig. 6), pl. 7 (fig. 3), pl. 10.

Marakei: 18771, 18790, 18907.

This species makes up the bulk of the algae collected from Marakei.

Ulva lactuca L., 1753: 1163; Dawson, 1954: 383, fig. 4.

Tarawa: 18833, 18843, 18854.

Wost of these collections are mere fragnents and at first glance look Iike small specimens of Ulva fasciata Delille. Upon microscopic examination of cross-sections, the cells seem to be relatively uniform in size and slightly taller than wide. In surface view the cells are polygonal and compact. These specimens fit the description of this entity in Gilbert's field manual.

Valonia aegagropila C. Ag., 1822: 429; Dgerod, 1952: 348, p1. 29b.

Tarawa: 18844 .

Vesicles $4-6 \mathrm{~cm}$ long and $1-2 \mathrm{~cm}$ wide forming a dense cushion in which both Hypnea and Jania are intermixed.

\section{PHAEOPHYTA}

Dictyota crenulatá J. Ag., 1847: 7, 94.

Marakei: 18919; Tarawa: 18880A.

All collections are fragments abuut $2 \mathrm{~cm}$ high with the characteristic proliferations on only a few portions of the edges.

Dictyota friabilis Setchell, 1926: 91, pl. 13 (figs. 4-7), pl. 20

(ficoli).

Marakei: 18785, 18792, 18300, 18906, 18943; Nukunau: 18894;

Tamana: 18952; Tarawa: 18836, 18858, 18880B.

This species of Dictyota occurs throughout the Pacific area growing either is an epiphyte on other algae or on coral or basalt rocks. It usually grows in clumps but can be found growing as individual thalli as seen in these collections from the Gilbert Islands.

Ectocarpus sp.

Narakei: 18777; Tarawa: 18373B.

These collections are of but a few filments each. The filaments of 18777 were found growing on a piece of cord, while $18873 \mathrm{~B}$ was found epiphytic on Padina. These specimens, both only about one millimeter tall, have sessile plurilocular organs up to $50 \mu$ long and $20 \mu$ wide, 
which are slender and frenerally oblong in shape. The filaments are narrow about $20 \mu$ wide and the cells are almost square in shape at the intercalary region. These filaments are too minute to be E. indicus Sonder while the plurilocular organs are not pyriform as in E. padinae (Buffham) Savageau.

\section{Padina sp.}

Tarawa: 18807, 13813, 18378i.

These collections are of fragments two cells thick throughout and producing oogonia.

Turbinaria ornata (Turner) J.Ag., 1348: 266; Dawson, 1954: 405, fig. 21. Abemama: 18895.

Typical of the species as often collected in Hawail.

\section{RHODOPHYTA}

Acanthophora spicifera (Vahl) Boergesen, 1910: 201, figs. 10, 19.

Tarawa: 10825, 18831, 18865, 18868, 18876.

All collections shrubby about 4-7 cm tall with Jania as the predominant epiphyte.

Ceramium fimbriatum Setchell \& Gardner, 1924: 777, pl. 26 (figs. 43-44); Dawson, 1954: 446, fig. 55a.

Marakei: 18779.

Thalli about $4 \mathrm{~mm}$ high with distinctly bulbous hairs protruding from the nodes.

Chondria repens Boergesen, 1920: 300, fig. 40.

Nulsunau: 10393.

A small mass of entangled thalli, with the largest thallus about $1 \mathrm{~cm}$ long. The habit of this alga resembles Boergesen's 1920 description and illustration of his species in all but one point. The tips of the branches of the Nukunau specimen are much more rounded than truncated.

Chondrococcus hornemanni (Mert.) Schmitz, 1895: 170.

Marakei: 18912.

This small piece of a thallus probably belongs to this species.

Falkenbergia hillebrandii (Bornet) Falkenberg = sporophyte generation of Asparagopsis taxiformis (Delille) Collins : Hervey; Feldmann \& Feldmarn, 1942: 89; Dawson, 1954: 414, fig. 25L; Taylor, 1960: 571, pl. 72 (fig. 8).

Marakei: 18776.

Thalli about $1.5 \mathrm{~cm}$ long and $30 \mathrm{H}$ wide with the three pericentral cells about 1.3 times as long than wide. Although both Dawson and Taylor 
cited above have illustrated this species, Dawson's illustration is much more representative of the lfarakei specimen.

Gelidiopsis intricata (Ag.) Vickers, 1905: 61; Dawson, 1954: 423, fizs. $34 a-d$.

Tarawa: 18055.

Thalli cylindrical about $2-3 \mathrm{~cm}$ long bearing terminal stichidia. Rhizoids and apical cells absent from these thalli.

\section{Gelidiopsis sp.}

Tarawa: 18852, 18866.

Very similar to Gelidiopsis intricata ( $\mathrm{Hg}$. ) Vickers except that the thalli are intertangled with each other.

Gelidium pulchellum (Turn.) Kütz. in Feldnann \& Hamel, 1936: 119, fig. 23 and pl. 1 (figs. 2, 3); Dawson, 1954: 421, fig. 32b.

Tarawa: 18873.

Thallus about $2 \mathrm{~cm}$ in height radiating from a common point of attachment.

Gelidium pusillum (Stackh.) Le Jolis, 1864: 139; Dawson, 1954: 420, fig. 3la-c.

Marakei: 18773, 18908, 18946; Tarawa: 18815B, 18829, 18845.

Most of the collections are of immature forms but seem to fit Dawson's illustration.

Hypnea cervicornis J. Ag., 1852: 451; Dawson, 1954: 435, fig. $46 \mathrm{~d}$.

Tarawa: 18377 .

The short branches of this specimen are not outstandingly cornuate or antler-like in shape as they are in Tanaka's illustration (1941, fig. 13c) but seem to be more similar to Dawson's illustration.

Hypnea esperi Bory, 1829: 157; Dawson, 1954: 436, fig. 46h-j.

Marakei: $18809 \mathrm{~B}, 18874,18835$.

Lon: thalli with numerous short branches on the main axis.

Hypnea nidulans Setchel1, 1924: 161, fig. 30; Tanaka, 1941: 246, fig. 18.

Marakei: 18772, 18784, 18791, 18798 , 18927, 18936, 18941; Tarawa: $18814,18810,18841,10851,18875$.

Thalli compressed, about $2 \mathrm{~cm}$ high, and with pointed short branches similar to Setchell's illustration.

Hypnea valentiae (Turn.) liontagne, 1840a: 161, Dawson, 1954: 436, fig. $46 \mathrm{I}, 47$.

Tarawa: 10812, 18867.

Forming thalli about $3 \mathrm{~cm}$ long. 


\section{Hypnea $s p$.}

Abemmama: 18896; Warakei: 18922; Tarawa: 18832.

Forming a very compact mass of thalli up to $2 \mathrm{~cm}$ high with branches about $1 \mathrm{~cm}$ long.

Jania adhaerens Lamx., 1816: 270; Boergesen, 1917: 195, fig. 184, 185, 187.

Tarawa: 18856.

Forming a compact mass of thalli and sand particles.

Jania capillacea Harvey, 1853: 34; Boergesen, 1917: 198, fig. 183.

A bemmama: 18903; Naralsei: 18775, 18786, 18789, 18794, 18905,

18938, 18940; Tarawa: 18830, 18842, 18361, 18882, 18886.

Forming a compact mass of thalli and sand particles intermixed,

with individual thallus about $77 \mu$ in diameter.

Jania tenella Kutzing, 1850: 41, pl. 85 (fig. 2); Dawson, 1956: 49, fig. 43.

Marakei: 18930.

Collection consisting of but a few small thalli.

Jania ungulata Yendo, 1902: 26, pl. 3 (figs. 7-8), pl. 7 (fig. 8).

Tarawa: 13324.

Small compact clumps consisting of thalli and sand particles.

Laurencia obtusa (Huds.) Lamour., 1813: 130; Taylor, 1960: 626.

Marakei: 18787, 18926; Tarawa: 18819.

Thalli forming clumps, cells cylindrical in cross-section with the larger cells in center of thalli about $66 \mu$ in diameter and those in the cortex about $27 \mathrm{\mu}$.

Laurencia okamurai Yamada, 1931: 200, pl. 5 (fig. b), text figs. F, G;

Taylor, 1950: 144; Dawson, 1956: 60, fig. 66 .

Tarawa: 18869, 18881.

The surface cells which project at the apex of the branches are very conspicuous.

Laurencia paniculata ( 61c-d.

A bemmama: 18902.

Thalli slightly compressed with cells cylindrical in cross-section.

Lophosiphonia obscura (Ag.) Falkenberg, 1901: 500; Dawson, 1954: 451, fig. $5 \mathrm{~d} d-e$.

Abemmama: 18900.

liain thalli prostrate with rhizoids present along the basal side. 
Polysiphonia coacta iseng, 1944b: 71, pl. 2; Dawson, 1954: 456, fig. $60 g-h$.

Marakei: 18774, 18782, 18921.

Thalli about $104 \mu$ wide at the widest and cortical cells shorter than broad.

Polysiphonia fragilis Suringer, 1870: 37, pl. 25B (figs. 1-4); Dawson, 1954: 452, fig. 60a-b.

Abemmama: 18897; Marakei: 13780, 18937.

Intermixed with blue-green algae. These thalli seem to agree with Dawson's discussion and illustration.

Polysiphonia subtilissima viontagne, 1840b: 199; Tseng, 1944b: 70, pl. I.

Marakei: 18911.

Growing as brown tufts about $5 \mathrm{~mm}$ high on coral pieces.

Polysiphonia tongatensis Harvey in Kuetzing, 1864: 14, p1. 41; Dawson, 1954: 454, fig. $60 \mathrm{~d}-\mathrm{e}$.

Tarawa: 18805, 18815A.

Tetrasporic thalli about $1-2 \mathrm{~cm}$ tall.

Tolypiocladia calodictyon (Horv.) Silva, 1952: 308, Dawson, 1956: 58, fig. 62 .

Tarawa: 18870.

Thalli intermixed with sand grains forming one intertangled mass. This specimen is well representative of Dawson's illustration.

Wurdemannia miniata (Imk. \& DC) Feldmann \& Hamel, 1934: 544, figs. 9-11; Dawson, 1954: 424, fig. 35.

Tarawa: 18308.

Thalli about 1-2 cm long with anastomoses present as seen in Dawson's illustration. 
Selected Bibliography

Catala, R.I.A. 1957. Report on the Gilbert Islands: some aspects of human ecology. Atoll Res. Bull. (59): 1-107.

Chapman, V.J. 1955. Algal collection from Funafuti Atoll. Pac. Sci. IX: $35^{\prime}+356$.

Cooper, M.J. 1964. Ciguatera and other marine poisoning in the Gilbert Islands. (Ścheduled for publication, Fac. sci., Oct. 1964).

Dawson, E.I. 1954. Marine plants in the vicinity of the Institut Oceanographique de Nha Trang, Viet Nam. Fac. Sci. VIII (4): 373-469, I map, figs. $1-63$.

-...-.... 1956. Some marine algae of the Southern Marshall Islands. Pac. Sci. $X(1)$ : 25-66, figs. $1-66$.

Dawson, E.Y., A.A. Aleem, \& B.W. Halstead. 1955. Harine algae from Palmyra Island with special reference to the feeding habits and toxicology of reef fishes. Allun Iancock Found. Fubl., Occ. Papers (17): 1-39, 1 map, figs. 1-13.

Doty, M.S., ¿. J. Mewhouse (unpublished). Manual on Hawaiian Phaeophyta.

Drouet, F. 1963. Ecophenes of Schizothrix calcicola. Froc. Acad. Nat. Sci., Phil. 115 (9): 261-281.

Egerod, L. 1352. An analysis of the siphonous Chlorophycophyta. Calif. Univ., Fubl., Bot. 25: 325-454, figs. 1-23, pls. 29-42.

Eubank, I. 1946. Hawaiian representatives of the genus Caulerpa. Calif. Univ., Publ., Bot. 10̂: 409-432, figs. 1-2.

Gilbert, W.J. (unpublished). Field manual on Iiawaiian Chlorophyta.

Helfrich, P. 1961. Fish poisoning in the tropical lacific. Haw. Har. Lab., Univ. of Hawaii, 1-16.

Helfrich, P., \& A.H. Banner. 1963. Experimental induction of Ciguatera toxicity in fish through diet. Nature 197 (4871): 1025-1026.

Helfrich, P., T. Piyarkarnchana, \&. P. Miles. (ms. in preparation). Relationship of certain aspects of the biology of reef fishes of the Iine Islands (Central Facific) to the probler of Ciguatera fish poisoning.

Hillis, I.J. 1959. A revision of the genus Halimeda. Inst. Har. Sci. VI: $321-403, \mathrm{pl} .1-12$.

Moul, E.T. 1257. Preliminary report on the flora of Onotoa Atoll, Gilbert Islands. Atoll Res. Bull. (57): 1-48. 
Randall, J. E. 1958. A review of Ciguatera, tropical fish poisoning, with tentative explanation of its cause. Bull. Mar. Sci. Gulf and Caribbean 8(3): 236-267.

Setchell, W. A. 1924. Vegetation of Tutuila Island, Carn. Inst., Wash. XX (part 1): 1-188, figs. 1-46.

Tanaka, T. 1941. The genus Hypnea from Japan. Hokk. Univ., Inst. Algol. Res., Sci. Papers 2(2): 227-250, figs. 1-21.

Taylor, W. R. 1950. Plants of Bikini. Univ. Mich. Press, 1-227, pls. $1-79$.

1960. Marine algae of the eastern tropical and subtropical coasts of the Americas. Univ. Mich. Press, 1-870, figs. 1-14, pls. $1-80$.

\section{Acknowledgment}

The writer is grateful to Drs. Maxwell S. Doty and Albert H. Banner of the University of Hawaii for their support which made this work possible. He is also indebted to Dr. Francis Drouet of the Academy of Natural Sciences of Philadelphia who so unselfishly found time to provide the Iist of identifications of blue-green algae; to Mrs. Jane Cooper of the Department of Cooperative Society, Suva, Fiji, who made the collections including the valuable field notes; to Dr. William J. Gilbert who helped the writer identify some of the green algae; to $\mathrm{Mr}$. Richard Buggeln, Miss Ernesta Galutira, Mr. Jan Newhouse, and Mr. Gavino Trono, Jr., all connected with the Botany Department, University of Hawaii, who gave at one time or another helpful advice in the identification of certain species of algae; and to Dr. Llewellya Hillis Colinvaux of the Department of Biology, Yale University, who verified and at times changed the writer's determinations of the species within the genus Halimeda.

This work was supported in part by the Public Health Service Grant EF-00216 from the Division of Environmental Engineering and Food Protection, and in part by National Science Foundation Grant GB-404. 